\title{
Assessment of the impact of NP fertilizer application depth on the rate of initial dry matter accumulation of maize (Zea mays L.)
}

\author{
Katarzyna Ambroży-Deręgowska ${ }^{1}$, Piotr Szulc ${ }^{2}$, Iwona Mejza ${ }^{1}$ \\ ${ }^{1}$ Department of Mathematical and Statistical Methods, Poznań University of Life Sciences, \\ Wojska Polskiego 28, 60-637 Poznań, Poland, e-mails: katarzyna.ambrozy@up.poznan.pl; \\ iwona.mejza@up.poznan.pl \\ ${ }^{2}$ Department of Agronomy, Poznań University of Life Sciences, Dojazd 11, 60-632 Poznań, \\ Poland, e-mail: piotr.szulc@up.poznan.pl
}

\section{SUMMARY}

\begin{abstract}
A field study was conducted at the Department of Agronomy of Poznań University of Life Sciences to determine the effect of the depth of NP fertilizer application in maize cultivation on the dynamics of initial maize growth, expressed in dry matter of a single plant at two juvenile maize stages. The adopted assumptions were verified on the basis of a four-year field experiment using four depths of NP fertilizer application, two nitrogen fertilizers and two nitrogen dose application dates. Thermal conditions in the early maize growing season had a significant effect on maize response to the depth of application of a phosphorus starting dose. Row fertilization (regardless of the depth of fertilizer application) was more effective than broadcast fertilization at both studied developmental stages.
\end{abstract}

Key words: fertilizer application, maize, plant growth phase, single plant dry weight, Tukey's test

\section{Introduction}

The phenological development of a plant consists of several developmental phases, each of which lasts for a specific period of time (Hay and Porter, 2006). Germination, vegetative growth, reproductive development, physiological maturity and aging are the five basic stages in the development of an annual crop (Thomas and Stoddart, 1980). Temperature, water and nutrient availability exert the strongest impact on the dynamics of developmental processes. Maize is very 
sensitive to nutrient deficiency (N, P), especially in the early stages of its growth (Fageria and Baligar, 2005). Maize malnutrition in the initial vegetation period disrupts the formation of leaves, ears and structural ear elements. These deficiency effects are visible very early, already at the 8-leaf stage (Szulc et al., 2017). At this stage of development, maize is very sensitive to deficiency of phosphorus, whose uptake depends on the concentration of orthophosphate ions in soil solution, as well as on the temperature and nutrition of other minerals (Sucunza et al., 2018). According to Subedi and Ma (2005), plant nitrogen malnutrition before this phase leads to an irreversible reduction in the number of ears and formed kernels, even by as much as $30 \%$. Therefore, correct recognition of cereal nutritional status during the initial vegetation period provides the possibility of predicting yield at a very early stage (Gaj et al., 2020). Hence, determining the optimal level of fertilization, ensuring the utilization of maize production potential, is one of the most important issues in agricultural practice. For this reason, field studies were conducted at the Department of Agronomy of Poznań University of Life Sciences to determine the effect of the depth of NP fertilization application in maize cultivation on the dynamics of initial growth. The adopted assumptions were verified on the basis of a four-year field experiment using four depths of NP fertilizer application, two nitrogen fertilizers and two nitrogen dose application dates.

\section{Methodology}

\subsection{Experimental field}

A field experiment was carried out at the Department of Agronomy of Poznan University of Life Sciences, in fields of the Gorzyń Experimental and Educational Unit, in the years 2015-2018. It was conducted for four years in the same splitsplit-plot design with 3 factors and 4 field replicates. The following factors were tested: $\mathrm{A}-1$ st order factor $-\mathrm{NP}$ fertilizer sowing depth [A1 $-0 \mathrm{~cm}$ (broadcast), $\mathrm{A} 2-5 \mathrm{~cm}$ (in rows), $\mathrm{A} 3-10 \mathrm{~cm}$ (in rows), $\mathrm{A} 4-15 \mathrm{~cm}$ (in rows)]; B $-2 \mathrm{nd}$ order factor - type of supplementary nitrogen fertilizer [B1 - ammonium nitrate, B2 - 
urea]; $\mathrm{C}$ - 3rd order factor - date of supplementary nitrogen fertilization [C1 before sowing, $\mathrm{C} 2$ - top dressing at the BBCH 15/16 stage]. The same level of mineral fertilization (100 kg Nha ${ }^{-1}, 70 \mathrm{~kg} \mathrm{P}_{2} \mathrm{O}_{5} \cdot \mathrm{ha}^{-1}$ and $\left.130 \mathrm{~kg} \mathrm{~K}_{2} \mathrm{O} \cdot \mathrm{ha}^{-1}\right)$ was applied in all experimental objects. Fertilization was balanced against phosphorus, which was applied at the whole required dose in the form of ammonium phosphate $\left(18 \% \mathrm{~N}, 46 \% \mathrm{P}_{2} \mathrm{O}_{5}\right)$, according to the experimental design under the 1 st order factor. $\mathrm{K}$ fertilization was performed before maize sowing in the form of potassium salt (60\%). Fertilizer coulters (on objects with initial fertilization) were set $5 \mathrm{~cm}$ aside from the seeds. Application depth of NP fertilizer was according to the 1st order factor levels. Maize sowing was performed with a precision seeder, with a built-in granular fertilizer applicator (Monosem). Gross plot size: $24.5 \mathrm{~m}^{2}$ (length $-8.75 \mathrm{~m}$, width $-2.8 \mathrm{~m}$ ). The net plot area for harvesting was $12.25 \mathrm{~m}^{2}$. Single plant dry weight at the 7-8-leaf stage (BBCH 17/18) and at the 8-9-leaf stage (BBCH 18/19) was tested. Ten plants were collected from each plot for analysis. Samples were collected with a spade; subsequently, the root was separated from the aerial part of the plant. After drying, the dry weight of one plant was determined.

\subsection{Meteorological conditions}

Thermal and humidity conditions in the maize growing seasons are presented in Table 1. The year 2018 was clearly the warmest and driest growing season. In turn, the largest sum of precipitation in the initial period of maize growth was recorded in 2016. The lowest average daily temperature $\left(12.8{ }^{\circ} \mathrm{C}\right)$ was recorded in 2017. Soil abundance in basic macronutrients and $\mathrm{pH}$ are given in Table 2.

\subsection{Statistical analysis}

Statistical analyses, such as analysis of variance (ANOVA) and Tukey's HSD (honestly significant difference) test for comparisons of pairs of means, were performed in the study years separately and over the years 2015-2018, according to the models of data obtained from the experiment, designed as a split-split-plot experiment (Gomez and Gomez, 1984). All calculations were carried out using 
the Statistica 13 software package (2017) and MS Excel software. Statistical significance was defined at $p$-value $<0.05$ for each source of variation.

Table 1. Average monthly air temperatures and monthly total precipitation for the growing season

\begin{tabular}{lcccc}
\hline \multirow{2}{*}{ Years } & \multicolumn{4}{c}{ Temperature $\left[{ }^{\circ} \mathrm{C}\right]$} \\
\cline { 2 - 5 } & IV & V & VI & Average/Sum \\
\hline 2015 & 9.3 & 13.9 & 16.9 & 13.4 \\
2016 & 9.6 & 16.3 & 19.9 & 15.3 \\
2017 & 7.3 & 13.7 & 17.4 & 12.8 \\
2018 & 12.9 & 16.9 & 18.5 & 16.1 \\
\hline Years & \multicolumn{4}{c}{ Rainfall [mm] } \\
\hline 2015 & 17.6 & 27.2 & 66.6 & 111.4 \\
2016 & 47.3 & 47.3 & 123.8 & 218.4 \\
2017 & 40.6 & 56.8 & 68.2 & 165.6 \\
2018 & 36.2 & 17.4 & 25.6 & 79.2 \\
\hline
\end{tabular}

Table 2. Nutrient contents and soil $\mathrm{pH}$ before establishing the experiment in maize growing seasons

\begin{tabular}{lcccc}
\hline \multirow{2}{*}{\multicolumn{1}{c}{ Specification }} & \multicolumn{4}{c}{ Years } \\
\cline { 2 - 5 } & 2015 & 2016 & 2017 & 2018 \\
\hline $\mathrm{P}\left[\mathrm{mg} \mathrm{P} \mathrm{kg}^{-1} \mathrm{dm}\right.$ of soil $]$ & 40.0 & 104.0 & 73.0 & 49.0 \\
$\mathrm{~K}\left[\mathrm{mg} \mathrm{K} \mathrm{kg}^{-1} \mathrm{dm}\right.$ of soil $]$ & 111.0 & 97.0 & 108.0 & 116.0 \\
$\mathrm{Mg}\left[\mathrm{mg} \mathrm{Mg} \mathrm{kg}^{-1} \mathrm{dm}\right.$ of soil $]$ & 29.0 & 44.0 & 53.0 & 53.0 \\
$\mathrm{pH}\left[1 \mathrm{~mol} \mathrm{dm}^{-3} \mathrm{KCl}\right]$ & 4.5 & 4.6 & 5.6 & 5.1 \\
\hline
\end{tabular}

\section{Results}

The different weather conditions in the study years 2015-2018 were reflected in the single plant dry weight (g) at both the 7-8-leaf stage (BBCH 17/18) and at the 8-9-leaf stage (BBCH 18/19). For this trait, significant interaction was identified between NP fertilizer sowing depth (A) and the year of research. The results in Table 3 indicate that the greatest mean of the single plant dry weight occurred in 2018 for both maize growth phases. However, for BBCH 17/18 the single plant dry weight increased significantly with the use of an NP fertilizer 
sowing depth (A) of at least $5 \mathrm{~cm}$ in rows. This effect was not significant for BBCH 18/19. In 2018, at both plant growth dates, the highest single plant dry weight (although not significantly different compared with other depths) was obtained for a sowing depth of $10 \mathrm{~cm}(3.90 \mathrm{~g})$ for $\mathrm{BBCH} 17 / 18$ and for a sowing depth of $15 \mathrm{~cm}(10.18 \mathrm{~g})$ for BBCH 18/19.

Table 3. Mean values for the combinations year $(\mathrm{Y}) \times$ depth of fertilization $(\mathrm{A})$

\begin{tabular}{cccc}
\hline Years (Y) & $\begin{array}{c}\text { Depths } \\
\text { of fertilization } \\
\text { (A) }\end{array}$ & $\begin{array}{c}\text { BBCH } \\
17 / 18 \text { phase } \\
(\mathrm{g})\end{array}$ & $\begin{array}{c}\text { BBCH } \\
18 / 19 \text { phase } \\
(\mathrm{g})\end{array}$ \\
\hline \multirow{4}{*}{2015} & A1 & $1.07 \mathrm{~g}$ & $5.26 \mathrm{~h}$ \\
& $\mathrm{~A} 2$ & $1.94 \mathrm{cdef}$ & $8.11 \mathrm{cde}$ \\
& $\mathrm{A} 3$ & $1.74 \mathrm{cdef}$ & $8.59 \mathrm{bcd}$ \\
& $\mathrm{A} 4$ & $1.48 \mathrm{efg}$ & $7.25 \mathrm{ef}$ \\
& $\mathrm{A} 1$ & $1.45 \mathrm{fg}$ & $6.23 \mathrm{fgh}$ \\
& $\mathrm{A} 2$ & $1.82 \mathrm{cdef}$ & $7.25 \mathrm{ef}$ \\
& $\mathrm{A} 3$ & $1.74 \mathrm{cdef}$ & $7.42 \mathrm{def}$ \\
& $\mathrm{A} 4$ & $1.97 \mathrm{cde}$ & $7.79 \mathrm{cde}$ \\
& $\mathrm{A} 1$ & $1.67 \mathrm{def}$ & $5.60 \mathrm{gh}$ \\
& $\mathrm{A} 2$ & $2.23 \mathrm{c}$ & $7.37 \mathrm{def}$ \\
& $\mathrm{A} 3$ & $2.19 \mathrm{c}$ & $6.87 \mathrm{efg}$ \\
& $\mathrm{A} 4$ & $2.02 \mathrm{~cd}$ & $6.45 \mathrm{fgh}$ \\
& $\mathrm{A} 1$ & $2.84 \mathrm{~b}$ & $8.98 \mathrm{abc}$ \\
& $\mathrm{A} 2$ & $3.76 \mathrm{a}$ & $9.80 \mathrm{ab}$ \\
& $\mathrm{A} 3$ & $3.90 \mathrm{a}$ & $10.09 \mathrm{a}$ \\
& A4 & $3.82 \mathrm{a}$ & $10.18 \mathrm{a}$ \\
\hline
\end{tabular}

Values in columns marked with at least one letter the same do not differ significantly $(\alpha=0.05)$

Irrespective of the experimental factors (Table 4), significantly the highest means of the single plant dry weights were recorded in 2018 for both plant growth phases (3.58 $\mathrm{g}$ for BBCH 17/18 and $9.76 \mathrm{~g}$ for $\mathrm{BBCH} 18 / 19)$. In the remaining years of the study (Table 4), the differences between the means of the single plant dry weight were not significant for BBCH 18/19. Only at the BBCH 17/18 phase, a significant difference was found in the mean values of the examined feature in 2015-2016 and 2017. 
Table 4. Mean values of single plant dry weight for the years and other factors

\begin{tabular}{cccc}
\hline Factors & $\begin{array}{c}\text { Levels } \\
\text { of factors }\end{array}$ & $\begin{array}{c}\text { BBCH 17/18 } \\
\text { phase }(\mathrm{g})\end{array}$ & $\begin{array}{c}\text { BBCH 18/19 } \\
\text { phase }(\mathrm{g})\end{array}$ \\
\hline \multirow{3}{*}{$\mathrm{Y}$} & 2015 & $1.56 \mathrm{c}$ & $7.30 \mathrm{~b}$ \\
& 2016 & $1.75 \mathrm{c}$ & $7.17 \mathrm{~b}$ \\
& 2017 & $2.03 \mathrm{~b}$ & $6.57 \mathrm{~b}$ \\
& 2018 & $3.58 \mathrm{a}$ & $9.76 \mathrm{a}$ \\
$\mathrm{A}$ & $\mathrm{A} 1$ & $1.76 \mathrm{~b}$ & $6.52 \mathrm{~b}$ \\
& $\mathrm{~A} 2$ & $2.43 \mathrm{a}$ & $8.13 \mathrm{a}$ \\
\multirow{3}{*}{$\mathrm{B}$} & $\mathrm{A} 3$ & $2.40 \mathrm{a}$ & $8.24 \mathrm{a}$ \\
& $\mathrm{A} 4$ & $2.32 \mathrm{a}$ & $7.92 \mathrm{a}$ \\
$\mathrm{C}$ & $\mathrm{B} 1$ & $2.18 \mathrm{~b}$ & $7.56 \mathrm{~b}$ \\
& $\mathrm{~B} 2$ & $2.27 \mathrm{a}$ & $7.84 \mathrm{a}$ \\
& $\mathrm{C} 1$ & $2.24 n s$ & $7.73 \mathrm{~ns}$ \\
\multicolumn{3}{c}{ Values in columns marked with at least one letter the same } \\
\multicolumn{2}{c}{ do not differ significantly $(\alpha=0.05), n s-$ not significant }
\end{tabular}

Over the study years, the results (Table 4) also indicate the significant impact of NP fertilizer sowing depth (A) on the single plant dry weight of maize both at the 7-8-leaf stage $(\mathrm{BBCH} 17 / 18)$ and at the 8-9-leaf stage (BBCH 18/19). Irrespective of the study year and other factors, the use of a depth of at least $5 \mathrm{~cm}$ resulted in a significant increase in the mean single plant dry weight at both plant growth dates. The highest mean single plant dry weights were obtained at $\mathrm{BBCH}$ $17 / 18$ for a depth of $5 \mathrm{~cm}(2.43 \mathrm{~g})$ and at BBCH 18/19 for a depth of $10 \mathrm{~cm}(8.24$ $\mathrm{g}$ ), but they did not differ significantly from the means for the other fertilizer sowing depths (Table 4). No significant interaction was found between year of research and type of supplementary nitrogen fertilizer (B). Over the study years and other factors, at both plant growth dates, a significantly higher mean single plant dry weight was obtained using urea as the supplementary nitrogen fertilizer than with ammonium nitrate (Table 4).

An extremely significant interaction was also obtained between the date of nitrogen application (C) and the study year (Y), but for BBCH 18/19 only. The highest mean single plant dry weight was recorded in 2018 (Table 5). The date of supplementary nitrogen fertilization, before sowing or by top dressing at the 
BBCH 18/19 phase, was irrelevant (mean weights did not differ significantly). Over the study years and irrespective of the type of the supplementary nitrogen fertilizer, the results also indicate significant interaction between of NP fertilizer sowing depth (A) and the date of supplementary nitrogen fertilization (C), but only for BBCH 18/19 (Table 5). They indicate that the mean single plant dry weight increased significantly with the use of an NP fertilizer sowing depth (A) of at least $5 \mathrm{~cm}$ in rows, whereas the greatest values of the mean weights were obtained for a sowing depth of $10 \mathrm{~cm}$ in rows. Other depths $(5 \mathrm{~cm}$ and $15 \mathrm{~cm})$ caused a negligible decrease in yields. Moreover, for each of these fertilizer sowing depths, the date of the supplementary nitrogen fertilization (C) was not significant.

Table 5. Mean values of single plant dry weight for the combinations $\mathrm{Y} \times \mathrm{C}$ and $\mathrm{A} \times \mathrm{C}$

\begin{tabular}{cccccc}
\hline $\begin{array}{c}\text { Years } \\
(\mathrm{Y})\end{array}$ & $\begin{array}{c}\text { Date of } \\
\text { nitrogen } \\
\text { application } \\
\text { (C) }\end{array}$ & $\begin{array}{c}\text { BBCH } \\
18 / 19 \text { phase } \\
\text { (g) }\end{array}$ & $\begin{array}{c}\text { Depth of } \\
\text { fertilization } \\
\text { (A) }\end{array}$ & $\begin{array}{c}\text { Date of } \\
\text { nitrogen } \\
\text { application } \\
\text { (C) }\end{array}$ & $\begin{array}{c}\text { BBCH } \\
18 / 19 \text { phase } \\
(\mathrm{g})\end{array}$ \\
\hline \multirow{2}{*}{2015} & $\mathrm{C} 1$ & $7.54 \mathrm{~b}$ & $\mathrm{~A} 1$ & $\mathrm{C} 1$ & $6.59 \mathrm{~b}$ \\
& $\mathrm{C} 2$ & $7.06 \mathrm{~b}$ & & $\mathrm{C} 2$ & $6.45 \mathrm{~b}$ \\
2016 & $\mathrm{C} 1$ & $7.12 \mathrm{~b}$ & $\mathrm{~A} 2$ & $\mathrm{C} 1$ & $7.95 \mathrm{a}$ \\
& $\mathrm{C} 2$ & $7.22 \mathrm{~b}$ & & $\mathrm{C} 2$ & $8.32 \mathrm{a}$ \\
2017 & $\mathrm{C} 1$ & $6.32 \mathrm{c}$ & $\mathrm{A} 3$ & $\mathrm{C} 1$ & $8.43 \mathrm{a}$ \\
& $\mathrm{C} 2$ & $6.83 \mathrm{c}$ & & $\mathrm{C} 2$ & $8.05 \mathrm{a}$ \\
2018 & $\mathrm{C} 1$ & $9.95 \mathrm{a}$ & $\mathrm{A} 4$ & $\mathrm{C} 1$ & $7.96 \mathrm{a}$ \\
& $\mathrm{C} 2$ & $9.57 \mathrm{a}$ & $\mathrm{C} 2$ & $7.87 \mathrm{a}$ \\
\hline \multicolumn{7}{l}{ Values in columns marked with at least one letter the same do not differ significantly $(\alpha=0.05)$}
\end{tabular}

\section{Conclusions}

- Thermal conditions in the early maize growing season had a significant effect on maize response to depth of application of the phosphorus starting dose. This was expressed as the amount of dry matter of a single plant that grew in the absence of thermal stress. 
- Row fertilization (regardless of the depth of fertilizer application) was more effective than broadcast fertilization at both studied developmental stages. As maize vegetation progressed, the effectiveness of this method decreased from $35.4 \%$ (BBCH 17/18) to $24.2 \%$ (BBCH 18/19).

- Maize fertilized with urea was characterized by significantly higher initial growth dynamics, expressed as dry matter of a single plant in juvenile phases, than with ammonium nitrate.

\section{REFERENCES}

Fageria N.K., Baligar, V.C. (2005): Enhancing nitrogen use efficiency in crop plants. Advances in Agronomy 88: 97-185.

Gaj R., Szulc P., Siatkowski I., Waligóra H. (2020): Assessment of the effect of the mineral fertilization system on the nutritional status of maize plants and grain yield prediction. Agriculture 10: 404, doi:10.3390/agriculture10090404.

Gomez K.A., Gomez A.A. (1984): Statistical procedures for agricultural research. Wiley, New York.

Hay R., Porter J. (2006): The Physiology of Crop Yield. 2nd Edition. Blackwell Publishing,

Subedi K.D., Ma B.L. (2005): Nitrogen uptake and partitioning in stay-green and leafy maize hybrids. Crop Science 45: 740-747.

Sucunza F.A., Gutierrez-Boem F.H., Garcia F.O., Boxler M. (2018): Long-term phosphorus fertilization of wheat, soybean and maize on Molisols: soil test trends, critical levels and balances. Eur. J. Agron. 96: 87-95.

Szulc P., Bocianowski J., Nowosad K., Rybus-Zając M., Waligóra H., Michalski T. (2017): The dynamics of a dry matter accumulation in the initial period of growth of four varieties of the "stay-green" type of maize (Zea mays L.). Pak. J. Bot., 49 (3): $1017-1022$.

Thomas H., Stoddart J.L. (1980): Leaf senescence. Annual Review of Plant Physiology 31: 83-111. 